\title{
GROWTH, YIELD AND STORABILITY OF ONION BULBS, AS AFFECTED BY IRRIGATION TREATMENTS AND CULTIVARS REFERRING TO WATER CONSUMPTION Kandil, A. A. ${ }^{*}$; A. A. Leilah ${ }^{*}$; A. Kh. Mostafa* and F. H. F. Hassan ${ }^{* *}$ * Faculty of Agric., Mansoura Univ., Egypt \\ ** Onion Research Section, Field Crop Research Inst., A.R.C., Egypt
}

\begin{abstract}
This work was carried out at Gemmeiza Agriculture Research Station Farm (Gharbeia Governorate) during 2006/2007 and 2007/2008 onion growth seasons, to study the effect of four irrigation regimes (one, two, three and four irrigations) and behavior of six new onion cultivars selected by Onion Research Section (Composite 9, Giza white, Behairy no pink, 1866 Globe, Giza Red and Giza 20) on growth, earliness bulb yield (ton/fed) and storability of bulbs as well as water consumption.

A separate experiment for each irrigation treatment was used with Randomize Complete Blocks Design in four replication.

The main obtained results from this investigation cane be summarized as follows:

1- Giving onion plants 2-3 irrigations increased average plant length (cm), number of leaves/plant, days to maturity, total yield (ton/fed), marketable yield (ton/fed) and culls yield (ton/fed). Whereas, decreasing bulbing ratio, dry matter percentage of plants, percentage of total loss in marketable yield during storage period of four months were increased with increasing of number irrigations to 2-3 irrigations. One, two and three irrigations saved 55.17 and $53.23 \%$ (about 1349.63 and $1238.84 \mathrm{~m}^{3} / \mathrm{fed}$ ), 35.13 and $37.85 \%$ (about 861.95 and $880.84 \mathrm{~m}^{3} / \mathrm{fed}$ ) and 17.84 and $15.54 \%$ (about 436.41 and $3611.67 \mathrm{~m}^{3} / \mathrm{fed}$ ) compared to giving four irrigations.

2- Giza Red and Giza 20 cultivars increased plant length (cm), number of leaves/plant, percentage of dry matter in plants, number of days to maturity, total yield (ton/fed) and marketable yield (ton/fed) as compared with other cultivars . Whereas, Giza White and Comp. 9 cultivars caused a decrease in plant height (cm), number of leaves/plant, fresh weight/plant and bulbing ratio. The higher culls bulbs was associated with 1866 Globe and Giza 20. Whereas, Giza White cultivar produced less culls bulbs ( $t / f e d)$. The highest total loss weight during storage period of four months was abserved with Comp. 9. Whereas, the less loss of weight was observed with Giza Red and Giza 20. Comp. 9 cultivar. consumed the highest irrigation water (1836.45 and $1785.58 \mathrm{~m}^{3} / \mathrm{fed}$ ) in both seasons. Whereas, Giza 20 and Behairy no Pink cultivars consumed less irrigation water.

3- The interaction between irrigation regimes and cultivars showed significant effects on marketable bulb yield (ton/fed) and total culls (ton/fed) in 2006/2007 season. The maximum marketable yield was observed with the treatment combination of giving 3-4 irrigations to Giza 20 cultivar. The maximum total culls bulbs (5.73 ton/fed) was observed under the treatment combinations of four irrigations and 1866 Globe cultivar.

Generally, it cane be concluded that giving 2-3 irrigations to Giza Red and Giza 20 cultivars saved suitable quantity of irrigation water and produced the highest onion bulbs yield with best quality.
\end{abstract}


Kandil, A. A. et al.

\section{INTRODUCTION}

Irrigation regime and cultivar of onion (Allium cepa L.) are most important factors affecting growth, yield and storability of bulbs. These two factors were studied to identify the most proper irrigation regime and cultivar. Several authors reported that irrigation intervals of three weeks produced the highest total and marketable yield and improved storability of bulbs. Culls yield decreased with more frequent irrigation, whereas maturity was delayed with more frequent irrigation.

Basilious (1975), El-Tabbakh et al. (1979) and Abu Grab (1987) they added that total loss in marketable yield during storage was enhanced with increasing irrigation level. Another authors, Mostafa and Leilah (1993), Mahmoud (1999) and El-Sharkawy-Amal et al. (2006) showed that irrigation of onion plant at 30 days intervals increased number of leaves/plant, bulb weight as well as total and marketable yield. Whereas, number of days to maturity and percentage of total loss in marketable yield during storage period were increased with widening of irrigation to 40 or 50 days.

Concerning onion cultivars, Shalaby and Kanddeel (1991), El-Kafoury et al. (1996), Mostafa (1998) and Mostafa and Abd El-Megid (1998) reported that marketable and exportable yield were greater for Shandweel 1 than Giza 6 Mohassan cultivars. Ori cultivar was the earliest in maturity and Behairy no Pink was the latest. They added that Yellow Creole and Comp. 16 had the heaviest yield. Hegazy and El-Sheikh (1999) found that Texas Early Yellow Grano X Giza 20 had heavier bulbs, more remarkable and total bulb yields followed by Composite 9 and Giza 20, while Assiut Globe, Yellow Creole and Composite 12 cultivars were the least in these characters Composite 12, 9 and 16 had more bulb yield. Giza 6, DMR and Assiut Globe cultivars. had less culls than Giza 20.

According, this investigation was carried out to evaluate six onion cultivars performance under different four irrigation regimes, with respect to bulb growth, yield and storability of onion referring to water consumption of onion plants.

\section{MATERIALS AND METHODS}

Eight field experiments were carried out at Gemmeiza Agriculture Research Station Farm (Gharbeia Governorate) during 2006/2007 and $2007 / 2008$ onion growth seasons, to study the effect of four irrigation treatments and performance new six onion cultivars on growth, earliness bulb yields (ton/fed) and storability of bulbs. Water consumption was determined by using orifice (James, 1988). A separate experiment for each irrigation treatment was used with Randomize Complete Blocks Design in four replication. The four irrigation treatments were; one at 45 days from transplanting, two irrigation at 45 and 105 days from transplanting, three irrigations at 45,90 and 125 days from transplanting and four irrigations at $45,75,105$ and 125 days from transplanting. 
The six onion cultivars were Composite 9 , which is a new nucleus selected by Onion Research Section from single cross between 10 American and 2 Egyptian cultivars, bulbs are uniform with high thick flat to globe shape and stored for long period ; Giza white which is a selection from Deltian types, bulbs are thick flat, white outer dry scales and excellent in keeping quality ; Behairy no pink which is a new Deltian selection free pink colour in bulb flesh, total soluble solids (TSS) and dry matter are relatively high and excellent in keeping quality ; 1866 which is a new nucleus selected from Behairy strain, its bulbs are high thick flat, white flesh and excellent in keeping quality ; Giza Red which is a selection from Behairy strain, red flesh had high content from total soluble solids and dry matter and excellent in keeping quality ; Giza 20 which is a selection from Egyptian Deltian types, bulbs are thick flat, white flesh, yellow brownish outer dry scales and excellent in keeping quality.

Onion seeds were hand drilled in the nursery bed on $10^{\text {th }}$ and $12^{\text {th }}$ October in the first and second seasons, respectively. Seedlings of nearly sixty days old when they usually were $25 \mathrm{~cm}$ in height were pulled tied and moved to the permanent land for transplanting on $5^{\text {th }}$ and $6^{\text {th }}$ January in the first and second seasons, respectively. Other cultural practices were carried out in the same manner prevailing in the region.

The previous crop was maize in both seasons. Experimental soil was clay loam with medium fertility. Monthly means of temperature, relative humidity at Gemmeiza (Gharbeia province) during onion growing seasons of 2006/2007 and 2007/2008 are listed in Table 1.

Table 1: Monthly temperature (Co) and relative humidity (\%) at ElGemmeiza during both seasons.

\begin{tabular}{|c|c|c|c|c|c|c|}
\hline & \multicolumn{3}{|c|}{ Temperature $\left(\mathbf{C}^{0}\right)$} & \multicolumn{3}{|c|}{ Relative humidity (\%) } \\
\hline & Min. & Max. & Mean & Min. & Max. & Mean \\
\hline \multicolumn{7}{|c|}{2007 season } \\
\hline December & 4.9 & 16.5 & 10.7 & 59.2 & 89.1 & 74.1 \\
\hline January & 4.8 & 16.3 & 10.5 & 58.1 & 88.2 & 73.6 \\
\hline February & 4.3 & 15.9 & 10.1 & 55.1 & 83.5 & 69.3 \\
\hline March & 6.0 & 18.8 & 12.4 & 52.7 & 83.2 & 67.9 \\
\hline April & 9.3 & 23.8 & 16.5 & 49.8 & 83.8 & 66.8 \\
\hline May & 12.8 & 28.3 & 20.5 & 41.0 & 73.4 & 57.2 \\
\hline \multicolumn{7}{|c|}{2008 season } \\
\hline December & 5.1 & 16.5 & 10.8 & 62.8 & 87.2 & 75.0 \\
\hline \begin{tabular}{|l} 
January \\
\end{tabular} & 5.0 & 16.5 & 10.7 & 62.6 & 86.1 & 74.3 \\
\hline February & 5.2 & 17.5 & 11.3 & 61.3 & 89.9 & 75.6 \\
\hline March & 6.3 & 22.1 & 14.2 & 49.9 & 80.1 & 65.0 \\
\hline April & 9.8 & 25.5 & 17.6 & 43.8 & 79.1 & 61.4 \\
\hline May & 12.4 & 27.7 & 20.0 & 41.8 & 71.5 & 56.6 \\
\hline
\end{tabular}

Well seedbed preparation for both nursery and permanent soils were done. Transplants 60 days ago were planted $7 \mathrm{~cm}$ apart in double - row ridges $60 \mathrm{~cm}$ width. Onion plants received $120 \mathrm{~kg} \mathrm{~N} / \mathrm{fed}$. One half at transplanting and the remained at 45 days from transplanting. Phosphorus 
was applied $15 \mathrm{~kg} \mathrm{P} \mathrm{P}_{5} / \mathrm{fed}$ with soil preparation. Other cultural practices for onion growing were followed.

Irrigation water was carried to the plots through a circular orifice and its quantity was calculated using equation of immersed orifice as described by James (1988).

$$
Q=0.61 \times 0.334 \times A \sqrt{h}
$$

Where; $Q=$ Quantity of irrigation water, $\mathrm{L} / \mathrm{sec}, \mathrm{A}=$ Area of orifice, $\mathrm{cm}^{3}$ and $\mathrm{h}=$ Effective water head orifice center, $(\mathrm{m})$.

The studied characters were means of plant length, average number of leaves/plant, foliage fresh weight/plant (g), dry matter percentage of plant and bulbing ratio (bulb diameter/neck diameter) at 130 days from transplanting. Earliness as average number of days from transplanting to maturity. Total bulbs yield (ton/fed), marketable bulbs yield (ton/fed), weight of total culls (ton/fed). Water consumption of onion plants for every irrigation treatment according to El-Sharkawy-Amal et al. (2006). Storability, it was determined as percentage of total loss in onion bulbs during storage period of four month.

Data were statistically analyzed using the analysis of variance technique according to Das and Giri (1986). Treatment means were compared using the New Least Significant of Difference as mentioned by Waller and Duncan (1969).

\section{RESULTS AND DISCUSSION}

\section{1- Irrigation treatments:}

Data presented in Tables 2 and 3 show that giving onion plants one or two irrigation after transplanting reduced plant length $(\mathrm{cm})$, fresh weight $(\mathrm{g})$ and increased dry matter percentage of plants, whereas average number of leaves/plant did not affected by irrigation treatments. These results are true in the two seasons. There was a tendency for plants to grow faster with increasing number of irrigations. Increasing the period between irrigations prohibit plants from available water for a longer time, thereby may depress metabolic activities within plant and negatively affect cell division in meristimic region of growth. Therefore, the reduction in some growth parameters that noticed to follow widened irrigation intervals is quite expected. Leaves number/plant was not markedly affected by irrigation regime. This may be due to the fact that leaves number of plant are a genetic character connected with plants cultivars. Similar results were reported by Basilious (1975), ElTabbakh et al. (1979) and Mostafa and Leilah (1993).

Data presented in Tables 3 and 4 show that dry matter percentage of plant and bulbing ratio were markedly affected by irrigation regime. Increasing number of irrigations gave the highest means of previous characters. Number of days from transplanting to maturity was significantly reduced with widened irrigations intervals. This may be explained on the base of reducing foliage growth with decreasing number of irrigations. Basilious (1975), El-Tabbakh et al. (1979), Abu Grab (1987) and Mostafa and Leilah (1993) came to the same conclusion. 
Table 2: Means of plant length (cm) and number of leaves/plant as affected by irrigation treatments of some onion varieties after 130 days from transplanting during 2006/2007 and 2007/2008 seasons.

\begin{tabular}{|c|c|c|c|c|}
\hline \multirow{2}{*}{\begin{tabular}{|l} 
Characters \\
Treatments \\
\end{tabular}} & \multicolumn{2}{|c|}{ Plant length (cm) } & \multicolumn{2}{|c|}{ Number of leaves/plant } \\
\hline & $2006 / 2007$ & $2007 / 2008$ & $2006 / 2007$ & $2007 / 2008$ \\
\hline \multicolumn{5}{|c|}{ A- Irrigation treatments: } \\
\hline One irrigation & 79.9 & 77.0 & 9.3 & 9.0 \\
\hline Two irrigations & 83.6 & 79.2 & 8.8 & 8.3 \\
\hline Three irrigations & 84.3 & 79.5 & 8.9 & 9.2 \\
\hline Four irrigations & 87.4 & 87.4 & 8.7 & 8.9 \\
\hline F. test & ** & ** & NS & NS \\
\hline LSD at $5 \%$ & 4.4 & 2.6 & - & - \\
\hline LSD at $1 \%$ & 5.8 & 3.6 & & \\
\hline \multicolumn{5}{|c|}{ B- Varieties: } \\
\hline Comp. 9 & 81.8 & 78.3 & 8.3 & 8.6 \\
\hline Giza White & 78.5 & 74.1 & 7.8 & 8.3 \\
\hline Behairy no Pink & 83.4 & 82.9 & 8.3 & 8.4 \\
\hline 1866 Globe & 84.0 & 81.8 & 9.1 & 8.2 \\
\hline Giza Red & 87.0 & 86.9 & 10.1 & 10.0 \\
\hline Giza 20 & 87.2 & 80.5 & 10.1 & 9.7 \\
\hline F. test & ** & ** & ** & ** \\
\hline LSD at $5 \%$ & 4.4 & 4.7 & 0.7 & 1.1 \\
\hline LSD at $1 \%$ & 5.9 & 6.5 & 0.9 & 1.5 \\
\hline \multicolumn{5}{|c|}{ C- Interactions: } \\
\hline & NS & NS & NS & NS \\
\hline
\end{tabular}

Table 3: Fresh weight per plant $(\mathrm{g})$ and dry matter percentage as affected by irrigation treatments of some onion varieties after 130 days from transplanting during 2006/2007 and 2007/2008 seasons.

\begin{tabular}{|c|c|c|c|c|}
\hline \multirow{2}{*}{\begin{tabular}{|l} 
Characters \\
Treatments
\end{tabular}} & \multicolumn{2}{|c|}{ Fresh weight/plant (g) } & \multicolumn{2}{|c|}{ dry matter Percentage } \\
\hline & $2006 / 2007$ & $2007 / 2008$ & $2006 / 2007$ & $2007 / 2008$ \\
\hline \multicolumn{5}{|c|}{ A- Irrigation treatments: } \\
\hline One irrigation & 181.1 & 182.9 & 14.1 & 14.1 \\
\hline Two irrigations & 201.0 & 195.8 & 14.0 & 13.0 \\
\hline Three irrigations & 205.3 & 198.5 & 13.0 & 13.1 \\
\hline Four irrigations & 211.1 & 204.6 & 11.2 & 10.9 \\
\hline F. test & * & NS & * & * \\
\hline LSD at $5 \%$ & 20.1 & - & 1.53 & 1.5 \\
\hline LSD at $1 \%$ & - & & - & - \\
\hline \multicolumn{5}{|c|}{ B- Varieties: } \\
\hline Comp. 9 & 218.9 & 218.3 & 11.0 & 10.8 \\
\hline Giza White & 167.2 & 146.0 & 16.3 & 14.7 \\
\hline Behairy no Pink & 184.4 & 174.4 & 11.7 & 11.3 \\
\hline 1866 Globe & 189.9 & 189.5 & 12.4 & 12.7 \\
\hline Giza Red & 202.9 & 207.1 & 13.9 & 14.0 \\
\hline Giza 20 & 234.4 & 237.1 & 13.2 & 13.1 \\
\hline F. test & $\star *$ & $\star * *$ & $\star *$ & $\star \star *$ \\
\hline LSD at $5 \%$ & 28.2 & 44.3 & 1.8 & 2.8 \\
\hline LSD at $1 \%$ & 37.0 & 59.0 & 2.4 & 3.7 \\
\hline \multicolumn{5}{|c|}{ C- Interactions: } \\
\hline & NS & NS & NS & NS \\
\hline
\end{tabular}


Kandil, A. A. et al.

Table 4: Means of bulbing ratio and earliness (days) as affected by irrigation treatments of some onion varieties during 2006/2007 and 2007/2008 seasons.

\begin{tabular}{|c|c|c|c|c|}
\hline \multirow{2}{*}{ Treatments } & \multicolumn{2}{|c|}{ Bulbing ratio } & \multicolumn{2}{|c|}{ Earliness (days) } \\
\hline & $2006 / 2007$ & $2007 / 2008$ & $2006 / 2007$ & $2007 / 2008$ \\
\hline \multicolumn{5}{|c|}{ A- Irrigation treatments: } \\
\hline One irrigation & 2.78 & 2.98 & 138.1 & 138.0 \\
\hline Two irrigations & 3.02 & 3.03 & 144.9 & 140.2 \\
\hline Three irrigations & 2.88 & 2.96 & 146.2 & 143.9 \\
\hline Four irrigations & 2.69 & 2.80 & 150.8 & 146.8 \\
\hline F. test & $* *$ & $\star \star$ & ** & ** \\
\hline LSD at $5 \%$ & 0.19 & 0.16 & 2.9 & 2.8 \\
\hline LSD at $1 \%$ & 0.25 & 0.22 & 3.9 & 3.8 \\
\hline \multicolumn{5}{|c|}{ B- Varieties: } \\
\hline Comp. 9 & 2.96 & 3.03 & 145.2 & 142.5 \\
\hline Giza White & 3.32 & 3.05 & 142.1 & 139.3 \\
\hline Behairy no Pink & 2.96 & 2.96 & 144.6 & 142.0 \\
\hline 1866 Globe & 2.90 & 3.10 & 143.7 & 141.0 \\
\hline Giza Red & 2.36 & 2.58 & 147.2 & 144.5 \\
\hline Giza 20 & 2.57 & 2.94 & 147.1 & 144.4 \\
\hline F. test & $\star *$ & ** & $* *$ & $\star *$ \\
\hline LSD at $5 \%$ & 0.16 & 0.24 & 3.0 & 2.0 \\
\hline LSD at $1 \%$ & 0.22 & 0.32 & 4.1 & 2.6 \\
\hline \multicolumn{5}{|c|}{ C- Interactions: } \\
\hline & NS & NS & NS & NS \\
\hline
\end{tabular}

Data in Table 5 show that decreasing number of irrigations from four to three, two and one irrigation gave total bulb yield as $16.142,18.225,17.341$ and 15.618 ton/fed, as an average of the two seasons, respectively. Marketable yield and total culls (doubles and bolters) in tons per feddan, followed the same trend of total yield/fed. The noticed reduction in bulb yields with decreasing number of irrigations may be due to the determined vegetative growth. Another explanation could be done as decreasing number of irrigations produced bulbs with less moisture content which reflected a reduction in weights. These results are in harmony with those obtained by Basilious (1975), El-Tabbakh et al. (1979), Abu Grab (1987) and Mostafa and Leilah (1993).

Data in Table 6 show that the percentage of total loss in weight of bulbs during storage period of four months as an index of bulbs storability decreased with decreasing number of irrigations, so the four irrigations exerted the higher record in both seasons. Results may be explained on the base that bulbs produced from less frequent irrigated plants are less of water content. These results are in harmony with those obtained by Basilious (1975), El-Tabbakh et al. (1979) and Mostafa and Leilah (1993).

\section{2- Cultivars performance:}

Data in Table 2 show that variation due to cultivars may be detected in indicated characteristics. The longest plants, increasing mean number of leaves and higher dry matter percentage of plants at 130 days from transplanting were associated with Giza Red and Giza 20 cultivars as an average of the two seasons. 
Table 5: Means of total bulb yield (ton/fed), marketable bulb yield (ton/fed) and total culls (ton/fed) as affected by irrigation treatments of some onion varieties during 2006/2007 and 2007/2008 seasons.

\begin{tabular}{|c|c|c|c|c|c|c|}
\hline \multirow{2}{*}{ Treatments } & \multicolumn{2}{|c|}{$\begin{array}{c}\text { Total bulb yield } \\
\text { (ton/fed) }\end{array}$} & \multicolumn{2}{|c|}{$\begin{array}{c}\text { Marketable bulb yield } \\
\text { (ton/fed) }\end{array}$} & \multicolumn{2}{|c|}{ Total culls (ton/fed) } \\
\hline & $06 / 2007$ & $07 / 2008$ & $06 / 2007$ & $07 / 2008$ & $06 / 2007$ & $07 / 2008$ \\
\hline \multicolumn{7}{|c|}{ A- Irrigation treatments: } \\
\hline One irrigation & 15.262 & 15.973 & 12.997 & 14.780 & 2.265 & 1.193 \\
\hline Two irrigations & 16.217 & 18.465 & 13.573 & 16.794 & 2.644 & 1.671 \\
\hline Three irrigations & 17.330 & 19.119 & 15.046 & 17.163 & 2.284 & 1.955 \\
\hline Four irrigations & 15.373 & 16.910 & 12.939 & 15.220 & 2.433 & 1.692 \\
\hline F. test & ** & $\star \star *$ & $\star \star *$ & ** & NS & * \\
\hline LSD at $5 \%$ & 0.346 & 0.483 & 0.280 & 0.564 & - & 0.191 \\
\hline LSD at $1 \%$ & 0.487 & 0.637 & 0.381 & 0.75 & - & - \\
\hline \multicolumn{7}{|c|}{ B- Varieties: } \\
\hline Comp. 9 & 17.639 & 18.729 & 14.618 & 16.885 & 3.021 & 1.846 \\
\hline Giza White & 12.342 & 12.742 & 11.225 & 11.425 & 1.116 & 1.316 \\
\hline Behairy no Pink & 15.867 & 17.788 & 14.040 & 16.168 & 1.830 & 1.618 \\
\hline 1866 Globe & 16.295 & 18.150 & 12.801 & 16.673 & 3.491 & 1.478 \\
\hline Giza Red & 15.814 & 18.631 & 13.309 & 17.174 & 2.505 & 1.456 \\
\hline Giza 20 & 18.315 & 19.666 & 15.839 & 17.610 & 2.476 & 2.056 \\
\hline F. test & ** & ** & ** & ** & ** & ** \\
\hline LSD at $5 \%$ & 1.170 & 1.065 & 0.640 & 0.450 & 0.474 & 0.148 \\
\hline LSD at $1 \%$ & 1.625 & 1.416 & 0.877 & 0.600 & 0.624 & 0.198 \\
\hline \multicolumn{7}{|c|}{ C- Interactions: } \\
\hline & ** & NS & ** & NS & ** & NS \\
\hline
\end{tabular}

Table 6: Percentage of total loss weight and applied irrigation water $\left(\mathrm{cm}^{3} / \mathrm{fed}\right)$ as affected by irrigation treatments of some onion varieties during 2006/2007 and 2007/2008 seasons.

\begin{tabular}{|c|c|c|c|c|}
\hline \multirow{2}{*}{ Treatments } & \multicolumn{2}{|c|}{ Total bulb loss weight (\%) } & \multicolumn{2}{|c|}{$\begin{array}{c}\text { Total Applied irrigation water } \\
\text { (cm3/fed) }\end{array}$} \\
\hline & $06 / 2007$ & $07 / 2008$ & $06 / 2007$ & 07/2008 \\
\hline \multicolumn{5}{|c|}{ A- Irrigation treatments: } \\
\hline One irrigation & 12.4 & 11.5 & 1096.9 & 1088.6 \\
\hline Two irrigations & 13.4 & 12.2 & 1584.9 & 1446.6 \\
\hline Three irrigations & 14.6 & 14.0 & 2010.5 & 1965.8 \\
\hline Four irrigations & 15.5 & 15.0 & 2446.9 & 2327.4 \\
\hline F. test & $\star *$ & ** & ** & ** \\
\hline LSD at $5 \%$ & 1.6 & 1.9 & 74.1 & 36.8 \\
\hline LSD at $1 \%$ & 2.2 & 2.5 & 101.5 & 48.4 \\
\hline \multicolumn{5}{|c|}{ B- Varieties: } \\
\hline Comp. 9 & 15.6 & 15.0 & 1836.4 & 1785.5 \\
\hline Giza White & 12.3 & 11.3 & 1778.1 & 1664.5 \\
\hline Behairy no Pink & 14.7 & 13.8 & 1780.0 & 1755.6 \\
\hline 1866 Globe & 14.3 & 13.6 & 1827.3 & 1698.2 \\
\hline Giza Red & 13.3 & 12.6 & 1783.9 & 1677.7 \\
\hline Giza 20 & 13.6 & 12.8 & 1703.1 & 1661.0 \\
\hline F. test & ** & ** & ** & * \\
\hline LSD at $5 \%$ & 1.4 & 1.6 & 64.6 & 73.2 \\
\hline LSD at $1 \%$ & 1.9 & 2.1 & 85.0 & - \\
\hline \multicolumn{5}{|c|}{ C- Interactions: } \\
\hline & NS & NS & NS & NS \\
\hline
\end{tabular}


Giza White and Comp. 9 cultivars were the shortest plants, less number of leaves/plant and decreased mean fresh weight/plant $(\mathrm{g})$. These results may be attributed to the genetic variations between onion cultivars. These results are in harmony with those obtained by El-Kafoury (1996), Mostafa (1998) and Mostafa and Abd El-Megid (1998).

Bulbing ratio was markedly affected by onion cultivars in both seasons as shown in Table 4. Earlier bulbing was observed with Giza White in both seasons, whereas later bulbing was recorded with Giza Red in both seasons. These results are in harmony with those obtained by El-Kafoury (1996), Mostafa (1998), Mostafa and Abd El-Megid (1998) and Hegazy and El-Sheikh (1999).

Table 4 show that the latest maturity plants was recorded with Giza Red cultivar. Whereas, Giza White was earlier in maturity. These results are in accordance with those obtained by El-Kafoury (1996) and Mostafa and Abd El-Megid (1998).

Data in Table 5 show that Giza 20 cultivar was associated with maximum total bulbs yield (18.315 and 19.666 ton/fed) followed by Comp. 9 which produced (17.639 and 18.729 ton/fed) in the first and second seasons, respectively. The lowest total yield (12.342 and 12.742 ton/fed) was observed with Giza White in the two seasons, respectively. Other onion cultivars were ranked in between. These results may be due to the genetic variations between onion cultivars. Mostafa (1998), Mostafa and Abd El-Megid (1998) and El-Kafoury (1999) came to the same conclusion.

Data in Table 5 revealed that marketable bulb yield (ton/fed) as affected by onion cultivars followed nearly the same trend of total bulb yield.

The higher culls bulbs (3.491 ton/fed) was observed with nucleus 1866 Globe cultivar in the first season, and Giza 20 (2.056 ton/fed) in the second season. The lower total culls (1.116 and 1.316 ton/fed) was recorded with Giza White in the first and second seasons, respectively. This may be due to the genetic variations between onion cultivars. These results are in harmony with those obtained by El-Kafoury (1996) and Mostafa and Abd El-Megid (1998).

Data in Table 6 show that the highest total loss weight during storage period of four months, was observed with Comp. 9 cultivar in both season. Whereas, the lowest total loss weight was associated with Giza White, Giza Red and Giza 20 cultivars with no marked differences in between. According to Mostafa and Abd El-Megid (1998), El-Kafoury et al. (1999) and Hegazy and El-Sheikh (1999), there was a varietal differences in storability of cultivars.

\section{3- Applied irrigation water (m3/fed):}

Data in Table 6 show that giving one irrigation at 45 days from transplanting saved about 55.17 and $53.23 \%$ of applied water as compared with giving four irrigation in the first and second seasons (1349.93 and $1238.84 \mathrm{~m}^{3} / \mathrm{fed}$ ), respectively. The treatment of two irrigation after transplanting saved about 35.13 and $37.85 \%$ of applied water as compared with giving four irrigations by rate of 864.95 and $880.84 \mathrm{~m}^{3} / \mathrm{fed}$, in the first and second seasons, respectively. The treatment of three irrigation after transplanting saved about 17.84 and $15.54 \%$ of applied water compared with 
giving four irrigations by rate of 436.41 and $361.67 \mathrm{~m}^{3} / \mathrm{fed}$ in the first and second seasons, respectively. El-Sharkawy-Amal et al. (2006) came to the same conclusion.

Regarding to onion cultivars, it is evident that there was a significant differences between onion cultivars in both seasons. Comp. 9 cultivar required the highest irrigation water (1836.45 and $1785.00 \mathrm{~m}^{3} / \mathrm{fed}$ ) in the first and second seasons, respectively as shown in Table 11 . Whereas, the least quantity of irrigation waster was observed with Giza 20 followed by Behairy no Pink cultivars in both seasons, respectively. These results are in harmony with those of Mostafa and Leilah (1993) and El-Sharkawy-Amal et al. (2006). 4- Interaction effects:

The interaction between irrigation treatments and onion cultivars had significant effect on total bulb yield (ton/fed), marketable bulb yield (ton/fed) and total culls bulb (ton/fed) in 2006/2007 season (Table 7,8 and 9).

The highest means of total bulb yield $(20.638 \mathrm{t} / \mathrm{fed})$ was observed with the treatment combination of giving three irrigations to Giza 20 cultivar. Whereas, the lowest total bulb yield $(11.178 \mathrm{t} / \mathrm{fed})$ was recorded with the treatment combination of Giza White cultivar and one irrigation (Table 7).

The highest means of marketable yield $(18.75 \mathrm{t} / \mathrm{fed})$ was observed with the treatment combination of giving three irrigations to Giza 20 cultivar. Whereas, the lowest marketable yield $(9.74 \mathrm{t} / \mathrm{fed})$ was recorded with the treatment combination of 1866 Globe cultivar and four irrigations (Table 8).

Table 7: Means of total bulb yield (ton/fed) as affected by the interaction between irrigation treatments and onion varieties during 2006/2007 season.

\begin{tabular}{|l|c|c|c|c|}
\hline \multicolumn{1}{|c|}{ Varieties } & One irrigation & $\begin{array}{c}\text { Two } \\
\text { irrigations }\end{array}$ & $\begin{array}{c}\text { Three } \\
\text { irrigations }\end{array}$ & $\begin{array}{c}\text { Four } \\
\text { irrigations }\end{array}$ \\
\hline Comp. 9 & 16.355 & 17.713 & 18.700 & 17.788 \\
\hline Giza White & 11.178 & 12.838 & 13.915 & 11.438 \\
\hline Behairy no Pink & 16.738 & 16.300 & 17.673 & 12.760 \\
\hline 1866 Globe & 16.228 & 15.570 & 17.903 & 15.478 \\
\hline Giza Red & 14.690 & 16.570 & 15.155 & 16.840 \\
\hline Giza 20 & 16.383 & 18.310 & 20.638 & 17.933 \\
\hline F. test & \multicolumn{4}{|c|}{1.436} \\
\hline LSD at 5\% & \multicolumn{4}{|c|}{1.903} \\
\hline LSD at 1\% & \multicolumn{4}{|l|}{} \\
\hline
\end{tabular}

Table 8: Means of marketable bulb yield (ton/fed) as affected by the interaction between irrigation treatments and onion varieties during 2006/2007 season.

\begin{tabular}{|l|c|c|c|c|}
\hline \multicolumn{1}{|c|}{ Varieties } & One irrigation & $\begin{array}{c}\text { Two } \\
\text { irrigations }\end{array}$ & $\begin{array}{c}\text { Three } \\
\text { irrigations }\end{array}$ & $\begin{array}{c}\text { Four } \\
\text { irrigations }\end{array}$ \\
\hline Comp. 9 & 14.07 & 12.10 & 16.14 & 16.16 \\
\hline Giza White & 10.26 & 11.52 & 12.52 & 10.61 \\
\hline Behairy no Pink & 14.73 & 14.48 & 16.23 & 10.72 \\
\hline 1866 Globe & 14.19 & 13.45 & 13.83 & 9.74 \\
\hline Giza Red & 11.91 & 13.82 & 12.81 & 14.70 \\
\hline Giza 20 & 12.83 & 16.07 & 18.75 & 15.71 \\
\hline F. test & \multicolumn{3}{|c|}{0.96} \\
\hline LSD at 5\% & \multicolumn{4}{|c|}{1.26} \\
\hline LSD at 1\% & \multicolumn{4}{|l|}{} \\
\hline
\end{tabular}


The highest total culls $(5.73 \mathrm{t} / \mathrm{fed})$ was observed under the treatment including the combination of 1866 Globe cultivar and four irrigations. Whereas, the lowest culls bulbs $(0.92 \mathrm{t} / \mathrm{fed})$ was recorded with the treatment including the combination of Giza White cultivar and one irrigation. This results may be attributed to the expression of genotype of cultivars with irrigation regime. Mostafa and Leilah (1993) came to the same conclusion(Table 9).

From all obtained results, it could be generally concluded that in case of cultivation onion in soil similar to that used in the experiment, it is recommended that Giza Red and Giza 20 are the suitable cultivars with given of 2-3 irrigations after transplanting. These treatments lead to an increase in total and marketable bulbs yield of high quality.

Table 9: Means of total culls (ton/fed) as affected by the interaction between irrigation treatments and onion varieties during 2006/2007 season.

\begin{tabular}{|l|c|c|c|c|}
\hline Varieties & $\begin{array}{c}\text { One } \\
\text { irrigation }\end{array}$ & $\begin{array}{c}\text { Two } \\
\text { irrigations }\end{array}$ & $\begin{array}{c}\text { Three } \\
\text { irrigations }\end{array}$ & $\begin{array}{c}\text { Four } \\
\text { irrigations }\end{array}$ \\
\hline Comp. 9 & 2.28 & 5.61 & 2.56 & 1.63 \\
\hline Giza White & 0.92 & 1.32 & 1.40 & 0.84 \\
\hline Behairy no Pink & 2.01 & 1.82 & 1.44 & 2.04 \\
\hline 1866 Globe & 2.04 & 2.11 & 4.08 & 5.73 \\
\hline Giza Red & 2.78 & 2.75 & 2.35 & 2.14 \\
\hline Giza 20 & 3.56 & 2.24 & 1.88 & 2.22 \\
\hline F. test & \multicolumn{3}{|c|}{0.65} \\
\hline LSD at 5\% & \multicolumn{5}{|c|}{0.86} \\
\hline LSD at 1\% & \multicolumn{5}{|l}{} \\
\hline
\end{tabular}

\section{REFERENCES}

Abu-Gerab, O.S. (1987). Effect of some cultural treatments on onion (Allium cepa L.). Ph. D. Thesis, Fac. of Agric. Minufiya Univ., Egypt.

Basilious, S.L. (1975). Effect of some cultural treatments on maturity yield and quality of onion (Allium cepa L.). M. Sc. Thesis, Fac. of Agric. Assiut Univ., Egypt.

Das, M.N. and N.C. Giri (1986). Design and analysis of experiments. $2^{\text {nd }}$ Ed. Johns Wiley \& Sons Inc. New York, USA.

El-Kafoury, A.K. ; A.K. Mostafa ; M.Y. Ibrahim and A.M. Hegazy (1996). Performance of some onion cultivars concerning yield quality, chemical constituents and storability of bulbs. J. Agric. Sci. Mansoura Univ., 21 (4): 1275-1285.

El-Sharkawy, Amal F. ; A.K. Mostafa and H.H. Abdel-Maksoad (2006). Effect of alternate furrow irrigation and transplanting distabce on water utilization efficiency for onion crop. Misr J, Agric. Eng., 23 (1): 137-150.

El-Tabbakh, A.E. ; A.G. Behairy and T.G. Behairy (1979). Soil moisture regime effect on yield of onion (Allium cepa L.) under different levels of nitrogen fertilizer. Res. Bull., Ain Shams Univ., Fac. of Agric., No. 991, $17 \mathrm{pp}$. 
Hegazy, A.M. and H.M. El-Shiekh (1999). Evaluation of growths yield, quality and storability of some new onion cultivars. J. Agric. Sci. Mansoura Univ., 24 (2): 445-452.

James, L.G. (1988). Principles of farm irrigation system design. John Wile \& Sons, New York, Chichester Brisbane Toronto Singapore, $410 \mathrm{p}$.

Mahmoud, Asmaa R. (1999). Effect of some agricultural treatment on productivity and quality of onion. Ph. D. Thesis, Fac. of Agric. Ain Shams Univ.

Mostafa, A.K. (1998). Yield and qualities of Giza 20 onion bulb as affected by transplanting date and source of seed. J. Agric. Sci. Mansoura Univ., 23 (1): 61-69.

Mostafa, A.K. and A.A. Leilah (1993). Effect of irrigation intervals and planting method on yield and quality of onion. Zagazig J. Agric. Res., 20 (1 A): 153-161.

Mostafa, A.K. and M.S. Abd El-Magid (1998). Evaluation of some onion cultivars to distance severity of downy mildew and purple blotch, bulb yields and quality. J. Agric. Sci. Mansoura Univ., 23 (2): 691-700.

Shalaby, G.I. and N.M. Kandeel (1991). Effect of some cultural practices on onion bulb production grown from sets planting dates, direction of ridges and cultivars. Assiut J. of Agric. Sci., 22 (5): 103-121.

Waller, R. A. and D. B. Duncan (1969). A bays rule for symmetric multiple comparison problem. Amer stat. Assoc. J., 1485-1503.

$$
\begin{aligned}
& \text { تأثير عدد الريات والأصناف على النمو والمحصول وصفات الجودة في البصل مـع }
\end{aligned}
$$

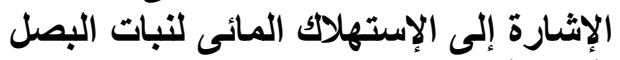

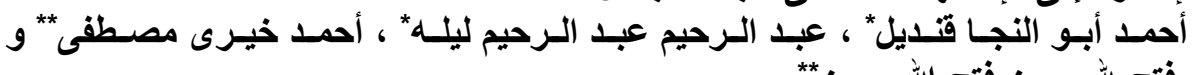

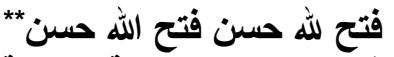

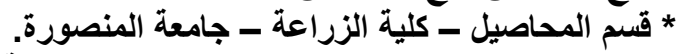

$$
\begin{aligned}
& \text { ** قسم بحوث البصل - معهد بحوث المحاصيل الحقلية ـ مركز البحوث الزراعية ـ مصر } \\
& \text { أجريت هذه الدراسـة فى مزرعة محطة البحوث الزر اعيدة بالجميزة (محافظة الغربية) }
\end{aligned}
$$

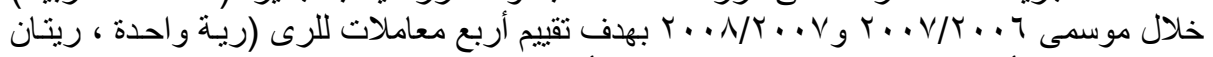

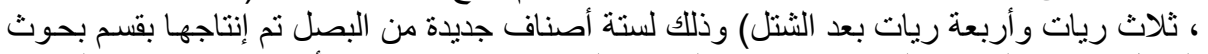

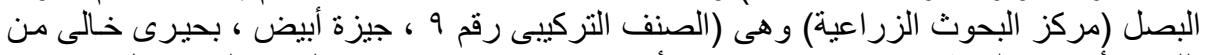

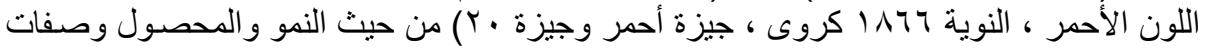

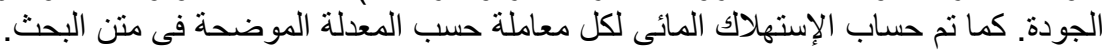

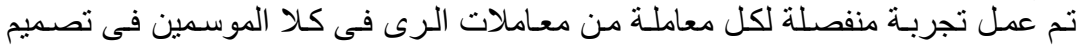

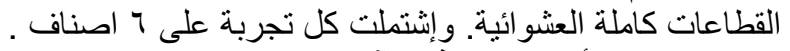

$$
\begin{aligned}
& \text { ويمكن تلخيص أهم النتائج فى الآتى: }
\end{aligned}
$$

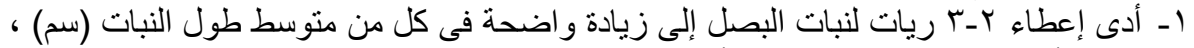

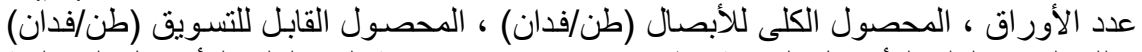

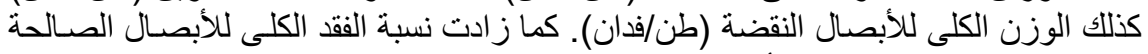

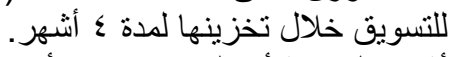

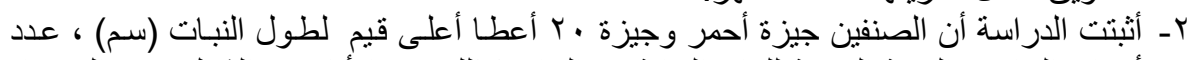

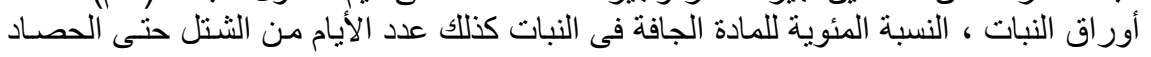




\section{Kandil, A. A. et al.}

بالمقارنة بالأصناف الأخرى. و قد أعطى الصنف 1474 كروي أعلى قيم فى وزن الأبصـال

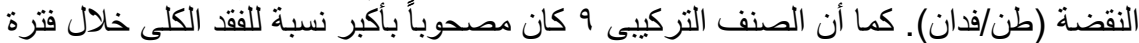

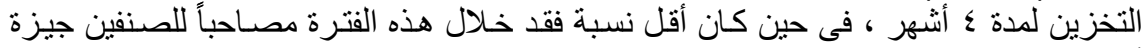

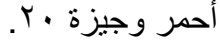

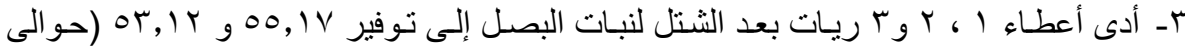

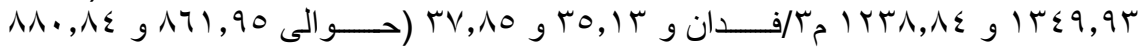

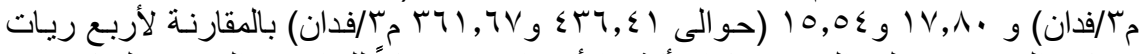

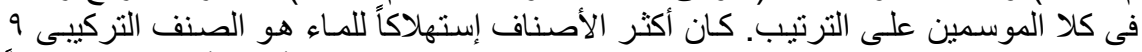

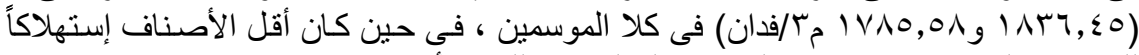

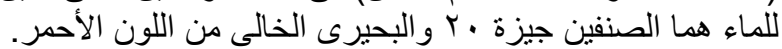

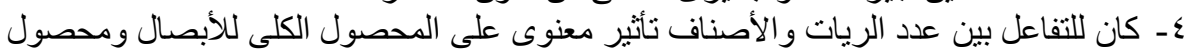

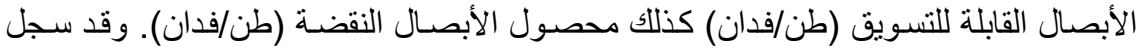

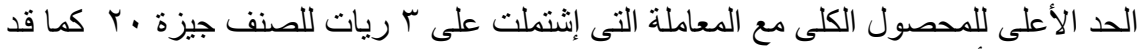

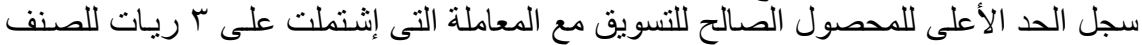

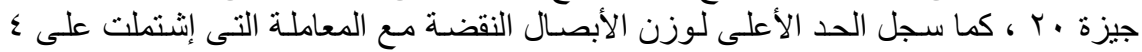

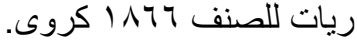

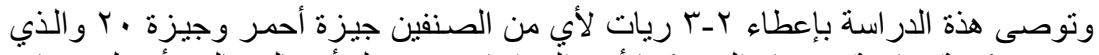
يؤدى إلى توفير كمية مناسبة من ماء الري كما أدى إلى إنتاج محصول أبصال عالئ عالي بأفضل صفات

كلية الزراعة - جامعة المنصورة مركز البحوث الزراعية
قام بتحكيم البحث

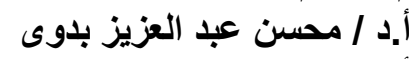
أ.د / محمد يوسف محمد ابر اهيم الدري 